\title{
David Oliver: The stress of sending patients home
}

\author{
David Oliver consultant in geriatrics and acute general medicine
}

Berkshire

"Look! It's that's bloody doctor who said he could go home." I heard those words directed at me in the local supermarket. I was shopping with my wife, and it was said in a threatening way, designed to be overheard, by what sounded like a middle aged man. The experience was unsettling. We left the shop, not looking up to see who'd said it, and to this day I don't know.

I mentioned this story over dinner to some other senior hospital doctors, who all described similar experiences in hospital corridors or doorways, or in public places during their leisure time.

That same week NHS Digital released national figures, the first in five years, on rates of emergency readmission to hospital within 30 days. ${ }^{1}$ This followed concerted lobbying from Healthwatch England, which said that transitions from hospital—and the communication processes and aftercare surrounding them-were a consistent concern for patients and families. ${ }^{23}$ The $13.8 \%$ readmission rate in $2017-18$ had risen less dramatically than I might have expected (from $12.5 \%$ in 2013-14), given our current bed pressures and patient demographic. The Nuffield Trust continued to publish its own analyses during those five years, showing similar numbers but remarking on rapid rises in patients readmitted within 24 hours or within seven days of leaving hospital. ${ }^{4}$

In my clinical day job and my policy and leadership work, I've encountered public perceptions that pressure on beds has led to patients being sent home too soon, and the Health Service Ombudsman has highlighted transition from hospital as a key area for complaints. ${ }^{5}$

There's no clear link between the speed of discharge and readmission rates, nor any clear evidence that most readmissions are related to poorly planned or premature discharge. ${ }^{6}$ Better organised acute care and discharge planning can lead to reduced stays and more patients being diverted to ambulatory care or sent home within a day or two of acute attendance, with no increase in readmission or mortality.

Hospital doctors don't have control over the quality or responsiveness of community services once a patient has left. But it can certainly be a shock and a major stressor for patients' families, or for paid care staff and community health services, to find themselves suddenly taking back the care of patients with complex needs who are still recovering from acute illness or injury and not yet back at the level they were. ${ }^{8}$

But what of the burden on hospital doctors? Yes, we work in multidisciplinary teams, but we generally carry the main responsibility for the decision to admit or discharge. And we're usually the ones at the coroner's inquest, or at the bereavement or complaint resolution meeting, or fielding the call from the patient advocacy and liaison team. It isn't just complaints and unhappy families we fear, but the distress we experience ourselves in worrying or knowing that our decisions have led to preventable harm.

During my career, emergency admissions and the number of beds occupied by stranded patients waiting for stepdown care services have risen, while bed numbers have fallen and occupancy has exceeded $90 \% .{ }^{910}$ Key acute and elective waiting time performance has slipped. ${ }^{11}$

Our response, in national NHS leadership and local clinical teams, has been a relentless focus on patient flow, early senior assessment, a "home first" approach, a push towards more "zero day admissions" and ambulatory care, and an imperative to minimise delays in going home for patients deemed medically fit to leave. ${ }^{12-14}$

Compared with when I started 30 years ago, we're under far more pressure to weigh priorities around bed use and to manage competing risks. No hospital discharge is risk-free. We must balance the risk of harm from ongoing admission against the risk of going home; the wishes of patients (often very keen to leave) against those of their families (often less keen); and, crucially, the needs and wants of patients currently occupying scarce acute beds against those of others who may need them more.

Despite my lengthy experience, these issues probably cause me more sleepless nights than any other aspect of the job. I can't be alone. So, how do fellow hospital doctors and clinical teams cope? How much support do they get from senior managers when things go wrong? It's a conversation we need to have: please do post your responses. 
Competing interests: See www.bmj.com/about-bmj/freelance-contributors. Provenance and peer review: Commissioned; not externally peer reviewed.

1 NHS Digital. Emergency readmissions published for first time in five years. 21 Mar 2019 https://digital.nhs.uk/news-and-events/latest-news/emergency-readmissions-publishedfor-first-time-in-five-years.

2 Healthwatch. Emergency readmissions: What's changed one year on? 14 Nov 2018. https://www.healthwatch.co.uk/report/2018-11-14/emergency-readmissions-whats-changedone-year.

3 Healthwatch. New plans to investigate rising emergency readmissions to hospitals announced in response to concerns raised by patients. 17 Jan 2019. https://www. healthwatch.co.uk/news/2019-01-17/new-plans-investigate-rising-emergency-readmissonshospitals-announced-response.

4 Nuffield Trust. Emergency readmissions. 30 Nov 2018. https://www.nuffieldtrust.org.uk/ resource/emergency-readmissions.

5 House of Commons Public Administration and Constitutional Affairs Committee. Follow-up to PHSO report on unsafe discharge from hospital. Fifth report of session 2016-17. 28 Sep 2016. https://publications.parliament.uk/pa/cm201617/cmselect/cmpubadm/97/97. pdf.

6 Oliver D. David Oliver: Who is to blame for older people's readmission?BM 2015;351:h4244. https://www.bmj.com/content/351/bmj.h4244.
7 Health Foundation. Improving patient flow. Apr 2013. https://www.health.org.uk/ publications/improving-patient-flow.

8 Healthwatch England. Safely home: What happens when people leave hospital and care settings? Jul 2015. https://www.healthwatch.co.uk/sites/healthwatch.co.uk/files/final report_healthwatch_special_inquiry_2015_1.pdf.

9 King's Fund. NHS hospital bed numbers: past, present, future. 29 Sep 2017. https://www. kingsfund.org.uk/publications/nhs-hospital-bed-numbers.

10 National Audit Office. Discharging older patients from hospital. 26 May 2016. https://www. nao.org.uk/report/discharging-older-patients-from-hospital/.

11 Morris J. Emergency care. Nuffield Trust. 26 Apr 2019. https://www.nuffieldtrust.org.uk/ news-item/emergency-care.

12 NHS Improvement. Red2Green campaign. https://improvement.nhs.uk/improvementoffers/red2green-campaign/.

13 NHS Improvement. Good practice guide: focus on improving patient flow. https:// improvement.nhs.uk/resources/good-practice-guide-focus-on-improving-patient-flow/.

14 Steventon A, Deeny S, Friebel R, Gardner T, Thorlby R. Briefing - emergency hospital admissions in England: which may be avoidable and how? May 2018. https://www.health. org.uk/sites/default/files/Briefing_Emergency\%2520admissions_web_final.pdf.

Published by the BMJ Publishing Group Limited. For permission to use (where not already granted under a licence) please go to http://group.bmj.com/group/rights-licensing/ permissions 